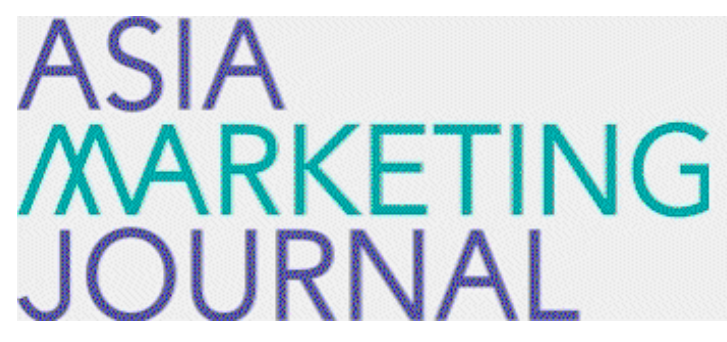

ASIA MARKETING JOURNAL

Volume 15 | Issue 1

Article 1

4-30-2013

\title{
A Case Study of Shanghai Tang
}

Klaus Heine

Michel Phan

Follow this and additional works at: https://amj.kma.re.kr/journal

Part of the Marketing Commons

\section{Recommended Citation}

Heine, Klaus and Phan, Michel (2013) "A Case Study of Shanghai Tang," Asia Marketing Journal: Vol. 15 :

Iss. 1 , Article 1.

Available at: https://doi.org/10.53728/2765-6500.1507

This Article is brought to you for free and open access by Asia Marketing Journal. It has been accepted for inclusion in Asia Marketing Journal by an authorized editor of Asia Marketing Journal. 


\section{A Case Study of Shanghai Tang: How to Build a Chinese Luxury Brand}

Klaus Heine* Michel Phan**

This case focuses on Shanghai Tang, the first truly Chinese luxury brand that appeals to both Westerners and, more recently, to Chinese consumers worldwide. A visionary and wealthy businessman Sir David Tang created this company from scratch in 1994 in Hong Kong. Its story, spanned over almost two decades, has been fascinating. It went from what best a Chinese brand could be in the eyes of Westerners who love the Chinese culture, to a nearly-bankrupted company in 1998, before being acquired by Richemont, the second largest luxury group in the world. Since then, its turnaround has been spectacular with a growing appeal among Chinese luxury consumers who represent the core segment of the luxury industry today. The main objective of this case study is to formally examine how Shanghai Tang overcame its downfall and re-emerged as one the very few wellknown Chinese luxury brands. More specifically, this case highlights the ways with which Shanghai Tang made a transitional change from a brand for Westerners who love the Chinese culture, to a brand for both. Westerners who love the Chinese culture and Chinese who love luxury. A close examination reveals that Shanghai Tang has followed the brand identity concept that consists of two major components: functional and emotional. The functional component for developing a luxury brand concerns all product characteristics that will make a product 'luxurious' in the eyes of the consumer, such as premium quality of cachemire from Mongolia, Chinese silk, lacquer, finest leather, porcelain, and jade in the case of Shanghai Tang. The emotional component consists of non-functional symbolic meanings of a brand. The symbolic meaning marks the major difference between a premium and a luxury brand. In the case of Shanghai Tang, its symbolic meaning refers to the Chinese culture and the brand aims to represent the best of Chinese traditions and establish itself as "the ambassador of modern Chinese style". It touches the Chinese heritage and emotions. Shanghai Tang has reinvented the modern Chinese chic by drawing back to the stylish decadence of Shanghai in the 1930s, which was then called the "Paris of the East", and this is where the brand finds inspiration to create its own myth. Once the functional and emotional components assured, Shanghai

\footnotetext{
* Assistant Professor of Luxury Marketing, EMLYON Business School, Shanghai. China ** Associate Professor of Luxury Marketing. EMLYON Business School, Shanghai. China(phan@em-lyon.com),
Corresponding Author
} 
Tang has gone through a four-stage development to become the first global Chinese luxury brand: introduction, deepening, expansion, and revitalization. Introduction: David Tang discovered a market gap and had a vision to launch the first Chinese luxury brand to the world. The key success drivers for the introduction and management of a Chinese luxury brand are a solid brand identity and, above all, a creative mind, an inspired person. This was David Tang then, and this is now Raphael Le Masne de Chermont, the current Executive Chairman. Shanghai Tang combines Chinese and Western elements, which it finds to be the most sustainable platform for drawing consumers. Deepening: A major objective of the next phase is to become recognized as a luxury brand and a fashion or design authority. For this purpose. Shanghai Tang has cooperated with other well-regarded luxury and lifestyle brands such as Puma and Swarovski. It also expanded its product lines from high-end custom-made garments to music CDs and restaurant, Expansion: After the opening of his first store in Hong Kong in 1994, David Tang went on to open his second store in New York City three years later. However this New York retail operation was a financial disaster. Barely nineteen months after the opening, the store was shut down and quietly relocated to a cheaper location of Madison Avenue. Despite this failure. Shanghai Tang products found numerous followers especially among Western tourists and became "souvenir-like" must-haves. However, despite its strong brand DNA, the brand did not generate enough repeated sales and over the years the company cumulated heavy debts and became unprofitable. Revitalizing: After its purchase by Richemont in 1998, Le Masne de Chermont was appointed to lead the company, reposition the brand and undertake some major strategic changes such as revising the "Shanghai Tang" designs to appeal not only to Westerners but also to Chinese consumers, and to open new stores around the world. Since then, Shanghai Tang has become synonymous to a modern Chinese luxury lifestyle brand.

Key words: Chinese luxury brand, company turnaround, luxury brand building

\section{Introduction to the Case}

Since the 1980s, the luxury market has grown at a much higher rate than the world economy. Bain \& Company (2011) estimates the global luxury market to reach almost 200 billion in 2012, and forecasts it to grow in the next few years by about five to six percent per year.
The optimism within the luxury industry is grounded to a large extent on the ongoing economic prosperity of Asian countries such as India and especially China (PwC, 2011). This is accompanied by forecasts that predict the Asian luxury market to grow by more than ten percent per year in the next few years (Bain \& Company, 2011). According to a study by Deloitte (2011), the number of millionaires in 
China will almost double by 2020 to about 2.2 million. There is an ever-growing group of people in China that is both, able and willing to consume luxury products. Asian culture is characterized by high levels of collectivism. power distance and face-consciousness, which make Asian consumers especially prone for luxury products ( $\mathrm{Lu}, 2008$ : Eng and Bogaert. 2010). This was demonstrated by the steep economic rise of Japan, which has become the world's biggest luxury market today (Bernstein Research, 2010). Only about 20 years ago, there was virtually no luxury market in China, The first Western luxury brands entered the Chinese market at the beginning of the $1990^{\circ}$ s, with Louis Vuitton leading the pack in 1992. Gucci grew its presence from only six stores at the beginning of 2006 to 56 outlets listed on its website this year. which exemplifies the rapid expansion of many luxury brands in recent years. Today. China has already surpassed the United States as the world's second biggest luxury market and is expected to become the world's largest luxury market by 2015 when it will account for about $20 \%$ of the global luxury market (McKinsey, 2011).

Paradoxically, in twenty years China has become one of the world's biggest consumer markets for luxury products, and yet, its own luxury brands are almost nonexistent. A major challenge for Chinese brands seems to be a problem with their country image. China is not associated with luxury, neither by foreigners, nor by Chinese (Montimer, 2007). However, looking back into the Chinese history, for hundreds of years the label "Made in China" was synonymous to a superior level of quality and craftsmanship. Starting from the $16^{\text {th }}$ century, many Western merchants went to China to trade European and American silver for Chinese luxury goods such as high-quality silk, ceramic, porcelain, and cashmere, and to learn the art of fine writing and printing (Armoudom, 2012). China's long history and tradition of craftsmanship provide actually a breeding ground for the development of luxury brands. But this will be a long and challenging journey. Japan started its shopping binge of European luxury about thirty years ago just as China does now. At that time, the "Made in Japan" label was seen as down-market, and is now associated with superior quality and cutting-edge (fashion) design (Montimer. 2007). However, there are still only very few Japanese luxury brands to be found today. Sanderson, Hille, and Friedman (2012) suggest that they have "struggled with the creative side of the industry."

Having said that, there are indeed a few developing (near-) luxury brands in China, and most of them are still in an experimental stage. They include Changyu wine (Yantai, since 1892). Mary Ching shoes (Shanghai, since 2009), Ne Tiger dresses (since 1992), Shanghai Vive cosmetics (Shanghai, since 2010), Longio watches (Shenzhen, since 1996), Sea Gull watches (Tianjin, since 1955), Tian Wang watches 
(Shenzhen, since 1988) and Zhaoyi jade jewelry (Beijing, since 2003). A special case is SheJi-Sorgere menswear, which is founded by state-controlled China Garments in 2011. Their products are designed in China but manufactured in Italy. There are also some successful Chinese fashion designers such as Uma Wang (since 2005), Qiu Hao (since 2006) and Xander Zhou (since 2007). In addition, some brands are based in Hong Kong such as Carnet (since 2003) and Emphasis by Chow Sang Sang jewelers, Ports 1961 (founded in Canada and since 1994 located in Hong Kong) and Dorian Ho fashion (since 1993). Another group consists of brands with foreign owners such as Shanghai Tang (Richemont, since 1998), Shang Xia (Hermès, since 2008) and Wenjun spirits (LVMH holds 55\% since 2007) and the jewelry house Qeelin in Hong Kong, which was set up by a French entrepreneur who hired a Chinese designer. The main question remains - how to develop a truly Chinese luxury brand that will be recognized as such by Chinese and non-Chinese consumers?

The objective of this paper is to analyze the major challenges and success factors for developing a Chinese luxury brand using a case study approach. We take reference to different emerging luxury brands in China, but, because of its outstanding success, we make a focus on Shanghai Tang. The paper relies on an exclusive in-depth interview with Raphael Le Masne de Chermont. CEO of Shanghai Tang. In addition, we also analyzed other public interviews with him and other published materials about the company.

\section{Company Profile}

Since its creation in 1994 by Sir David Tang Wing-Cheung, a Hong Kong businessman, Shanghai Tang has been the pioneering Chinese luxury brand with international presence. David Tang has interpreted Chinese culture and craftsmanship with a vibrant sophistication and dynamism of the $20^{\text {th }}$ century, utilizing the best quality Chinese materials from luxurious Chinese silk to the finest Mongolian cashmere and precious Chinese jade, to create a range of contemporary luxury products proudly made by Chinese. However, as the company struggled, David Tang decided to sell the major share holding of Shanghai Tang to the luxury group Richemont in 2001. Before he moved on to new business ventures, David Tang stayed on for a couple of years during the handover of the top responsibilities to Raphael Le Masne de Chermont, who has spent his entire professional life within the Richemont group. After a Master degree in Management, Raphael successively worked for Cartier, Piaget, Officine Panerai and Baume \& Mercier in the UK, Belgium and Hong Kong. When he took over the top job at Shanghai Tang, his mission was to transform an ailing 
niche brand of Shanghai traditional tailoring into the first profitable Chinese lifestyle brand. With its mission as the global ambassador of contemporary Chinese Chic, Shanghai Tang showcases Chinese traditions and craftsmanship through a universe of affordable luxury products including ready-to-wear for women, men, and children, as well as accessories, homeware and lifestyle experiences through lounge music collections and the Shanghai Tang Café that offers a modern Chinese cuisine experience. From a colorful and nostalgic art deco concept store in Hong Kong (Pedder Street), Shanghai Tang has evolved into an international network of 40 boutiques in the world's most prestigious shopping districts, including London, New York, Shanghai, and soon Paris (2013) and Tokyo (2014). Today Shanghai Tang is no longer a new brand: and since its launch of almost 20 years ago, it has already built up some heritage and experienced an exciting history with ups and downs from which other potential Chinese luxury brands can learn.

\section{Basic Market Entry Strategies into the Luxury Segment}

The background of the existing Chinese luxury brands (see above) reflects the basic market entry strategies. There are two major ways of getting into the luxury segment - one is through the designers. Some highly talented Chinese fashion designers may be successful in developing their businesses from small designer brands into international luxury brands, which will survive independently of their creators. Many well-known Western luxury brands were set up by designers and have survived well after their creators are gone, such as Yves St Laurent, Chanel and Dior to name a few. The other major way into the luxury market is exemplified by Shanghai Tang. The brand was created by a businessman who identified a market potential for creating a Chinese luxury brand using Chinese natural assets and craftsmanship. Most of the potential new players in the Chinese luxury market come from Chinese entrepreneurs, who are not designers. However, cooperation between these two groups might be promising.

Allying with a Western luxury group is another strategic option that is used by Shanghai Tang. The brand benefits from the competencies and the network of the Richemont group. In the design team, $50 \%$ of designers are Chinese and $50 \%$ are Europeans and they work in pairs. The mix of cultures is a good catalyst for creativity while keeping the brand DNA well rooted in the Chinese culture. They all have extensive experience in designs from either their own design businesses or other Western luxury brands such as Gucci, Kenzo, or Issey Miyake. Shanghai Tang regularly or- 
ganizes field trips to Europe or Asia for its designers and encourages them to travel to new places to learn and get inspired. Armoudom (2012) regards the cooperation with Western partners as a major success driver for Chinese luxury brands. The combination of Western marketing expertise and Chinese mythology boosts the success of Wenjun spirits probably far beyond its possibilities without LVMH. Selling parts of their brand to a foreign luxury group can benefit Chinese companies with, by far, higher profits and values of their remaining shares. In addition to the financial gains, these Western allies can contribute to the improvement of the general image of Chinese products, which will facilitate the development of future Chinese luxury brands. A Frenchman set up the luxury brand Qeelin in Hong Kong and hired a Chinese designer to add Chinese elements to his products. Similar to this model, a Chinese entrepreneur could set up a brand and hire Chinese designers and Western marketers.

Another option for Chinese businesses would be to acquire European luxury brands: this is already a trend, which probably will become more apparent in the near future. For instance, the Italian Cerruti 1881 menswear brand was acquired by the Hong Kong Li \& Fung group, which also bought 80 percent of the French luxury fashion brand Sonia Rykiel. Another Hong Kong-based YGM group also acquired the British Aquascutum and China's Weichai Group acquired 75 percent of Italy's Ferretti yachts (Sanderson et al., 2012). However, although it can help Chinese firms to build their marketing knowhow and improve their reputation, these luxury brands will remain European: a change in ownership does not change the brand's roots and DNA. Therefore, this strategy does not help (in the short-term) to create truly Chinese luxury brands. Another strategic decision is the selection and investment in a particular luxury segment that is intrinsically linked to a country image. Luxury watches seem to be highly associated with Switzerland, luxury chocolates with Belgium, luxury cars with Germany, luxury shoes with Italy, and so on. Brands can from benefit from a positive country image that is connected to a product category. Similarly there are promising product categories for which Chinese entrepreneurs could benefit from a positive "Made in China" image, such as cashmere and silk products, furniture, porcelain and stoneware, spirits, tea, and also stationary products including writing instruments and letter paper.

After the market entry strategies are defined. managers of a potential Chinese luxury brand need to decide what the brand should stand for. To some extent, they need to follow the "codes of luxury" in order to be perceived as luxurious. In addition, they need to think about the symbolic meaning and benefits that their brand can add to their products. The concept of brand identity can help managers in these tasks. This framework will be introduced in the next paragraph. The China-specific adaptation of this 
concept will be discussed with reference to Shanghai Tang.

\section{The Concept of Brand Identity as a Framework for the Creation of Luxury Brands}

According to the modern consumer identity orientation in brand management, brands are regarded as images in the minds of consumers and other target groups (Esch, 2010), which are designed by companies to identify their products (Kotler, Keller, Brady, Goodman and Hansen, 2009). Dependent on human identity, brands are also ascribed as having an identity (Kapferer, 2008). The brand identity comprises all brand associations that are intended by the company (Aaker, 1996). It corresponds to the intra-company self-perception of a brand, which determines precisely how the brand should appear to the external target groups. As shown in Figure 1, the brand image constitutes the anti-pole of the brand identity, corresponds with the public perception of a brand and is the result of brand positioning by various marketing measures and other consumer experiences with a brand (Esch 2010: Kotler et al., 2009). The elements of brand identity can be mainly divided into two main components. The first component covers the functional, mainly physical and product-related associations, while

〈Figure 1) The Status of Brand Identity in Brand Management

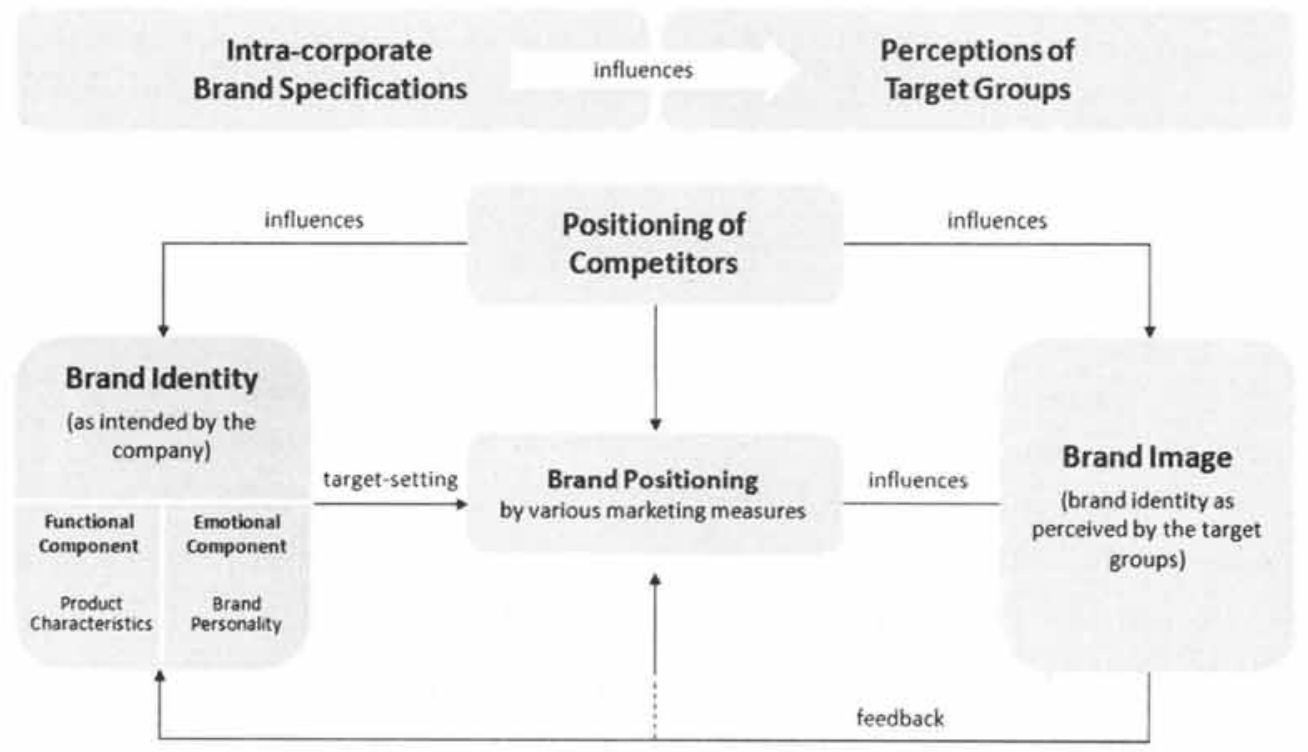

Source: Esch (2010, p. 91) 
the other component includes the abstract and emotional brand associations (Esch, 2010: Aaker. 1996).

\subsection{The Functional Component: How to Make a Brand Luxurious}

This component mainly covers the physicalfunctional characteristics of a brand's products, for example, the double-stitched seam or the canvas of a Louis Vuitton bag (Esch 2010). These attributes lead to functional and psychosocial brand benefits such as the longevity of a Louis Vuitton bag because of its double-stitched seam, or the quality because of its unique canvas (it is the material most commonly used for Louis Vuitton bags, other than leather). Luxury brands are highly associated with their respective core products. All luxury brands have some functional characteristics in common, which can be referred to as constitutive characteristics of luxury products and brands. Study results suggest that consumers perceive luxury products to have six major characteristics. As shown in Figure 2, these characteristics include price, quality, aesthetics, rarity, extraordinariness and symbolism (Heine and Phan, 2011).

These characteristics may be viewed as dimensions ranging from a minimum level that is absolutely necessary to a maximum level that corresponds to the highest form of luxury. Luxury consumers differ in their expectations of their ideal luxury products, which do not re- quire all characteristics to reach the highest level. Consequently, luxury companies can adjust the luxury level of the major characteristics to a specific combination depending on the preferences of their target group. The luxuriousness of a product increases proportionally with the increasing level of at least one of those characteristics. Not surprisingly, the degree of luxuriousness is one of the major means of differentiation for luxury brands (Esteve and Hieu-Dess, 2005).

Deepening the understanding of these characteristics gives some guidance for trading-up mass-market goods and to create luxury products and brands. Each luxury brand aims at evoking associations about the constitutive characteristics within their target group to at least some degree. Therefore, these characteristics could be referred to as the "codes of luxury" that any luxury brand has to comply with (see also Kapferer and Bastien 2009b).

However, a brand is qualified as a luxury brand only if it actually succeeds in evoking luxury-specific associations in the minds of its target groups. As illustrated in Figure 1, it has to transfer its intended brand identity into the minds of its target consumers without it being distorted by other external influences, such as the marketing measures of competitors. Meeting this challenge requires great expertise in adequate luxury marketing techniques. Luxury companies may compete for the best possible perception of their products by their target 
〈Figure 2〉 The Constitutive Characteristics of Luxury Products and Brands

\begin{tabular}{|c|c|c|c|}
\hline $\begin{array}{l}\text { Major } \\
\text { Characteristics }\end{array}$ & $\begin{array}{l}\text { Manufacturing } \\
\text { Characteristics }\end{array}$ & $\begin{array}{l}\text { Concrete } \\
\text { Product Characteristics }\end{array}$ & $\begin{array}{l}\text { Abstract } \\
\text { Product Characteristics }\end{array}$ \\
\hline Price & & Price & \\
\hline \multirow[t]{6}{*}{ Quality } & $\begin{array}{l}\text { Expertise of } \\
\text { manufacturer }\end{array}$ & Material \& Components & Durability \& Value \\
\hline & $\begin{array}{l}\text { Manufacturing } \\
\text { complexity }\end{array}$ & $\begin{array}{l}\text { Construction \& } \\
\text { Function principle }\end{array}$ & Comfortability \& Usability \\
\hline & & Workmanship & $\begin{array}{l}\text { Functionality \& } \\
\text { Performance }\end{array}$ \\
\hline & & Features & Safety \\
\hline & & Product size & \\
\hline & & Service & \\
\hline Aesthetics & & & Aesthetics \\
\hline Rarity & & Rarity & \\
\hline Extraordinariness & & & Extraordinariness \\
\hline Symbolism & & & Symbolism \\
\hline
\end{tabular}

Source: Heine and Phan (2011)

groups. As many luxury brands are true masters in influencing consumer perceptions, Catry (2003) refers to them appropriately enough as the "great pretenders."

This stage of brand development is particularly challenging for Chinese companies that aspire to enter the luxury market. First of all, they need to deeply understand what a luxury brand actually is, the "codes of luxury", and based on that, the specific marketing techniques that allow creating perceptions of luxuriousness. Allying with a Western partner seems to be helpful to overcome this challenge. Born into a wealthy family of Chinese entrepreneurs and well educated in England, founder Sir David Tang certainly had no problems in creating an image of prestige and luxury. He did not use so much the superlative pricing strategy, but emphasized above all the quality and craftsmanship of his products utilizing the best of Chinese materials, ranging from luxurious Chinese silk to the finest Mongolian cashmere and precious Chinese jade, Shanghai Tang's unique Imperial Tailoring collection offers made-to-measure services supported by a strong heritage of legendary Shanghainese tailoring. However, much of the Shanghainese tailoring skills and fashions were lost during the Cultural Revolution, with now only a few houses employing these ancient techniques, Shanghai Tang being one of the last bastions. 


\subsection{The Emotional Component: Giving a Symbolic Meaning to a Brand}

The emotional component covers the nonfunctional symbolic meanings of a brand. A key characteristic of luxury products and brands is their specific symbolic meaning, which marks the major difference between the premium and luxury segment (Kapferer and Bastien, 2009b). There is no other product category with a similar relevance of symbolic benefits, which often even exceed their functional benefits (Vernier and Ghewy, 2006). As the symbolic meaning of luxury brands refers to a large extent to human personality traits (Vigneron and Johnson 2004), the emotional component corresponds largely with the concept of brand personality. According to Aaker (1997) the brand personality refers "to the set of human characteristics associated with a brand." The personality of Christian Dior, for example, might be seen as elegant, glamorous and provocative. Luxury products cannot symbolize anything, but they need to comply with the worldview and taste of the upper class (Kapferer and Bastien 2009b). The personality concept especially for luxury brands includes five major personality dimensions including modernity, prestige, sensuality, understatement and eccentricity (see Figure 3). Modernity, for instance, relates to the temporal perspective of a brand, and eccentricity the level of discrepancy from social norms and expectations. This personality concept provides potential founders of a luxury brand some guidance for the development of symbolic meaning. Similar to a painter who looks at his color palette to know his options, marketers can use the personality concept to give their brand some meaning, a personality or even an "aura". Figure 3 gives an overview of the identity of luxury brands including the constitutive characteristics of luxury brands and the dimensions of luxury brand personality: both components are closely linked. According to the functional component, luxury products are characterized by high symbolic meaning, which is covered to a great extent by the dimensions of luxury brand personality. When marketers aim to enhance their brand with great symbolic meaning, they have to ask themselves what they actually want to symbolize - and then they can find some answers and guidance from the dimensions of luxury brand personality. Chinese designers, who strive to develop their designs into a luxury brand, cannot make much use of the brand personality concept. Their own creative personality represents the brand (personality). The concept is more suitable for Chinese businessmen, who want to develop a new luxury brand. Of course, both groups have to understand the high relevance of symbolic meaning within the luxury segment. While the functional component and the specific aesthetics of luxury are (still) heavily influenced by Western countries, the emotional component and the symbolic 
〈Figure 3〉 Overview about the Concept of Luxury Brand Identity
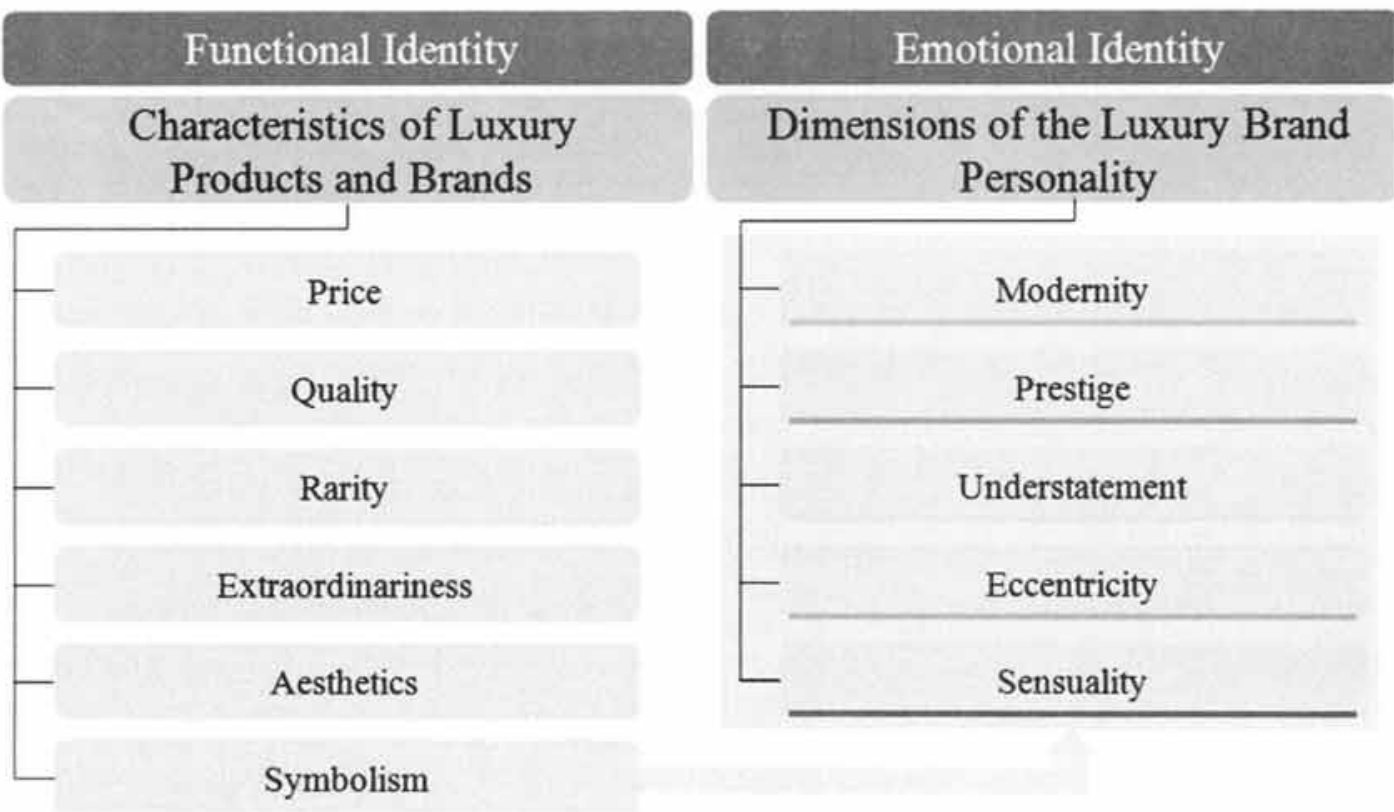

Source: Heine (2012)

meaning can, and have to originate from the Chinese culture. China is a high-context culture, and its rich history and mythology offer, by far, enough material for symbolic benefits of Chinese luxury brands.

\subsubsection{Changing consumer preferences: China's New Cultural Revolution}

Despite the almost inexhaustible sources of symbolic meaning in the Chinese culture, there were substantial obstacles for the development of successful China-specific meaning in luxury. Luxury was and still is highly associated with Western culture, and therefore Western luxury brands were generally perceived as being more luxurious and prestigious, and Chinese brands such as Shanghai Tang and Frankie Xie were clearly at a disadvantage, "Western stuff was hot. Chinese stuff was not." (Heine and Trommsdorff, 2008, p. 41). However, this is changing. "There is a growing sentiment that 5,000 years of civilization has created superior ways of doing things that have only been revived today" (Prasso, 2007). Prasso (2007) argues that "sinofication" even becomes a challenge for Western luxury brands and that they have "to figure out how to stay in this game, offering products that appeal to China's growing sense of Chineseness - to its national pride and strength of tradition." On the other hand, this trend is benefiting Chinese luxury brands 
such as Shanghai Tang and its strategy in targeting Mainland Chinese consumers. Le Masne de Chermont also reports: "We have to explain that it is okay to be luxury and Chinese" (Movius, 2009). By doing so, Shanghai Tang helps changing people's minds towards Chinese luxury (Bogert and Elliot, 1997). This trend is highly related to the generation of "young emperors", who were born after 1978 when the national reform started and into a new era of China represented by a growing economy and the "one child" policy. Their parents and grandparents concentrated all their resources and efforts on their single child/grand-child, which makes this generation the best educated, the most confident, but also the most self-centered and ambitious among all the living generations in China. They are avid and savvy and frequently self-indulgent consumers (HedrickWong, 2007). This generation will change the Chinese luxury market: the "nouveau riche" attitude of today will be replaced by sophistication and a more discrete taste and style (Degen, 2009). It is reasonable to expect that this proud generation is increasingly comfortable with its heritage and much more receptive to Chinese luxury brands (Montimer, 2007).

The symbolic meaning of Shanghai Tang refers to a big part of the Chinese culture: the brand even aims to represent the best of Chinese traditions and to establish itself as "the ambassador of modern Chinese style" (Reena, 2005). It touches Chinese heritage and emotions. Tang has reinvented modern Chinese chic by drawing back to the stylish decadence of Shanghai in the 1930s, which was then called the "Paris of the East" - this is where the brand finds the inspiration to create its own myth and to tell touching stories with their advertising campaigns. By drawing inspiration from their beloved home country, Shanghai Tang offers something that quite simply can't be found anywhere else in the world. Shanghai Tang may follow the tradition of established luxury labels associated with a specific national aesthetic: it has the chance to become the Chanel of China (Reena, 2005). Throughout the year, regular seminars are planned to ensure that all employees also know exactly where the company is heading at and what the brand aims to stand for in the market. As shown in Figure 4, the spring/ summer 2012 campaign, for instance, captures the undying spirit, charm, and economic might of China with powerful and evocative images. It is their symbolic meaning and vision that make these images as powerful and expressive. A brand without a deep emotional identity ultimately has not much to say and is likely to create just shallow and insignificant adverts (which can be observed by the German brand Joop!). Shanghai Tang and some other Chinese brands such as NE Tiger improved their brand storytelling (Armoudom, 2012), which is the crucial ability to exploit Chinese cultural heritage for their brands. 
〈Figure 4〉 Shanghai Tang Spring/Summer 2012 Campaign

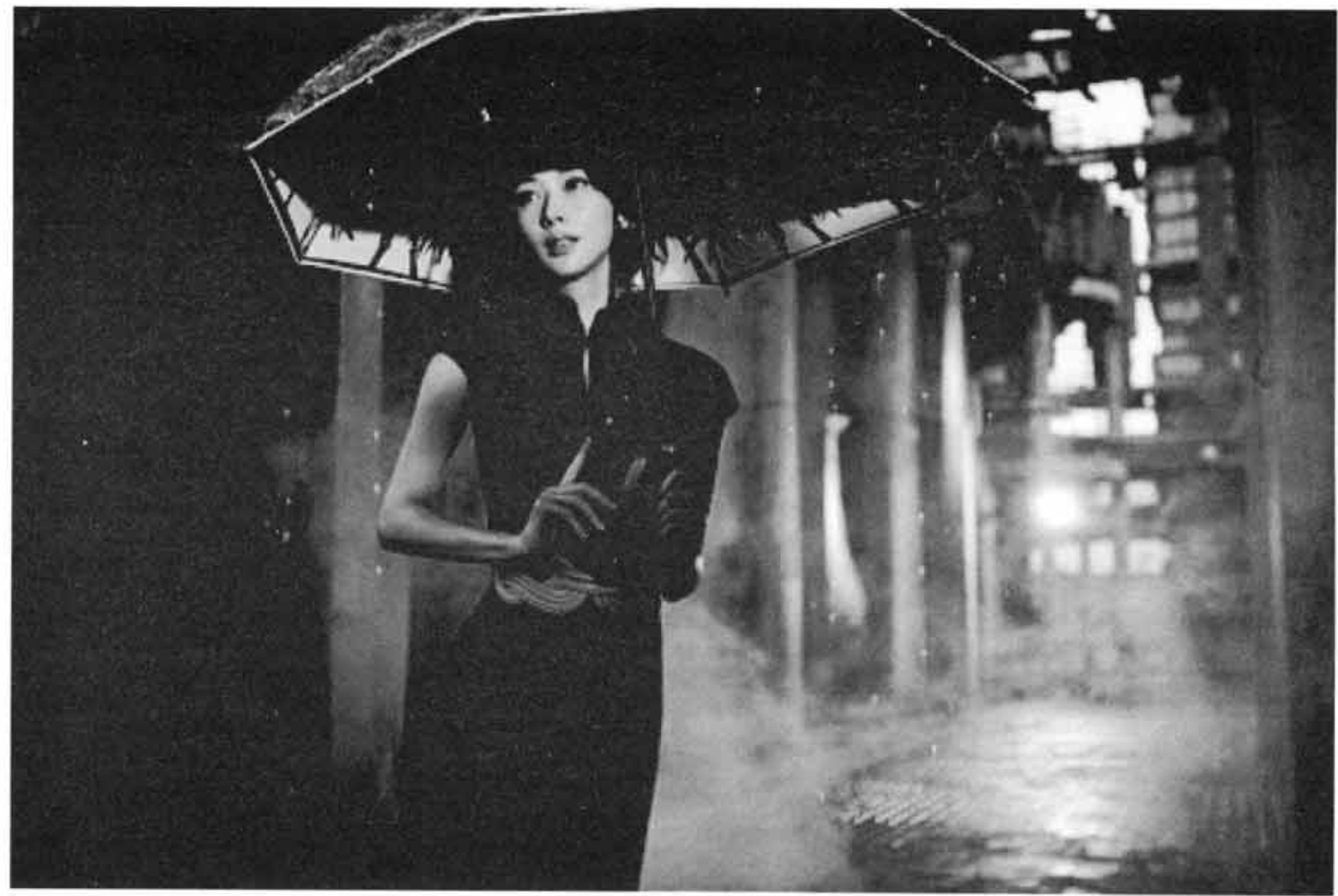

Source: shanghaitang.com

\section{Luxury Brand Management}

After creating the identity of a luxury brand, the actual brand management starts with the introduction followed by a deepening and expansion phase. Over the years, a brand can encounter difficulties, which may require a brand repositioning followed again by deepening and expansion phases. This demonstrates that brand management follows certain stages, but is a dynamic process that only ends with the elimination of a brand. As outlined in
Figure 5, these phases of luxury brand management are characterized by typical objectives and success factors. This framework is used in the subsequent paragraph to analyze the major success factor of developing Chinese luxury brands with a particular reference to Shanghai Tang.

\subsection{Introduction}

David Tang discovered a market gap and had a vision to launch the first Chinese luxury brand. Key success drivers for the introduction 
〈Figure 5〉 Stages of Luxury Brand Management

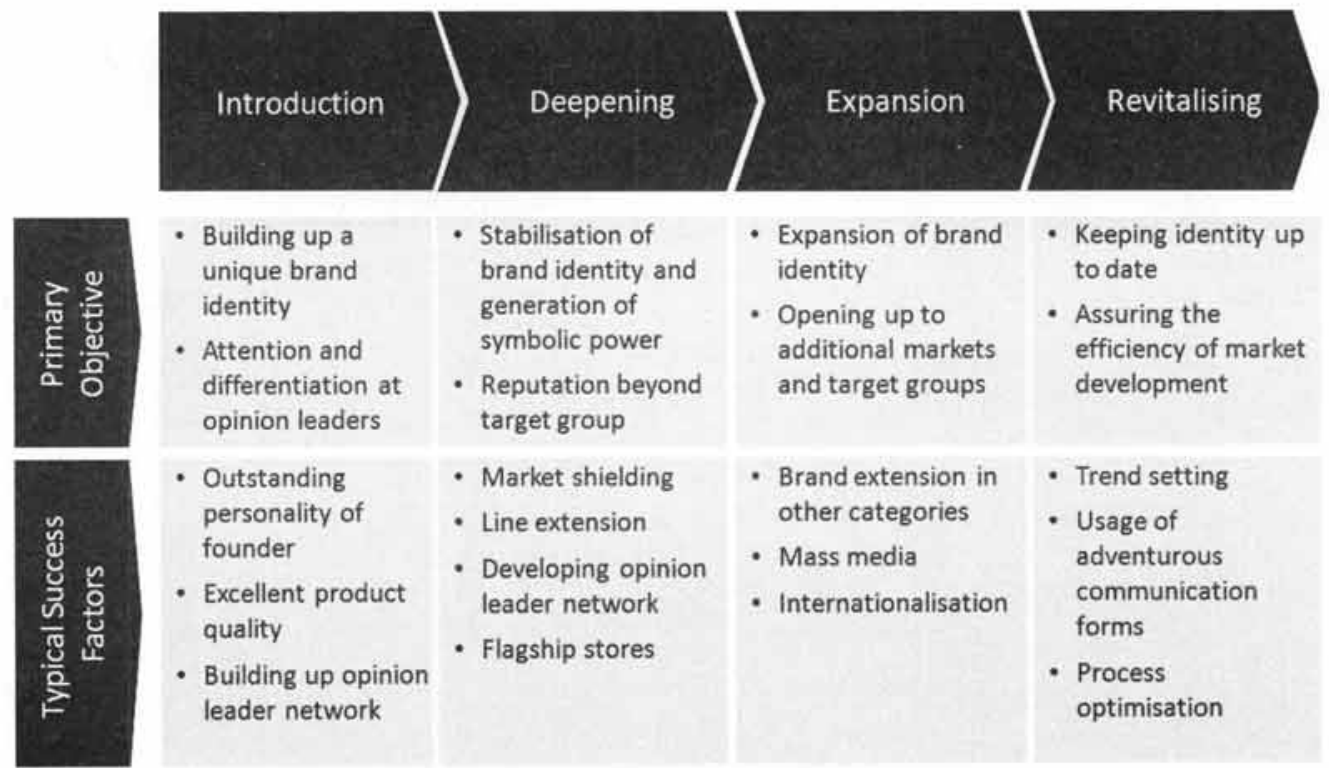

Source: Meffert and Lasslop (2003)

and the management of a Chinese luxury brand are a solid brand identity (as discussed above) and above all a creative mind, an inspired person. This was David Tang and this is now Raphael Le Masne de Chermont. Shanghai Tang and almost all Chinese luxury ventures combine Chinese and Western elements, which they find to be the most sustainable platform for drawing consumers (Armoudom, 2012). As this is true for most luxury brands, successful Chinese luxury brands start from a design innovation that draws attention and media coverage (Nueno and Quelch ,1998).

\subsection{Deepening}

A major objective of the next phase is to be- come recognized as a luxury brand and a fashion or design authority. For this purpose, Shanghai Tang has cooperated with other well-regarded luxury and lifestyle brands such as Philipp Treacy, Puma and Swarovski (Jones and Conti. 2006). In contrast with many other luxury brands, Shanghai Tang is less keen on celebrity marketing. Le Masne de Chermont is scathing about this marketing practice and "its ability to make people sheep-like followers of celebrity": he argues that it would boots Shanghai Tang's sales if singer Beyoncé were seen with a Shanghai Tang bag, but he claims that she should buy it herself because she genuinely likes it (Montimer 2007). This strategy is itself not a success driver on its own, but it demonstrates again a visionary brand manager, who 
〈Figure 6〉 The first Shanghai Tang store in Hong Kong on Pedder Street

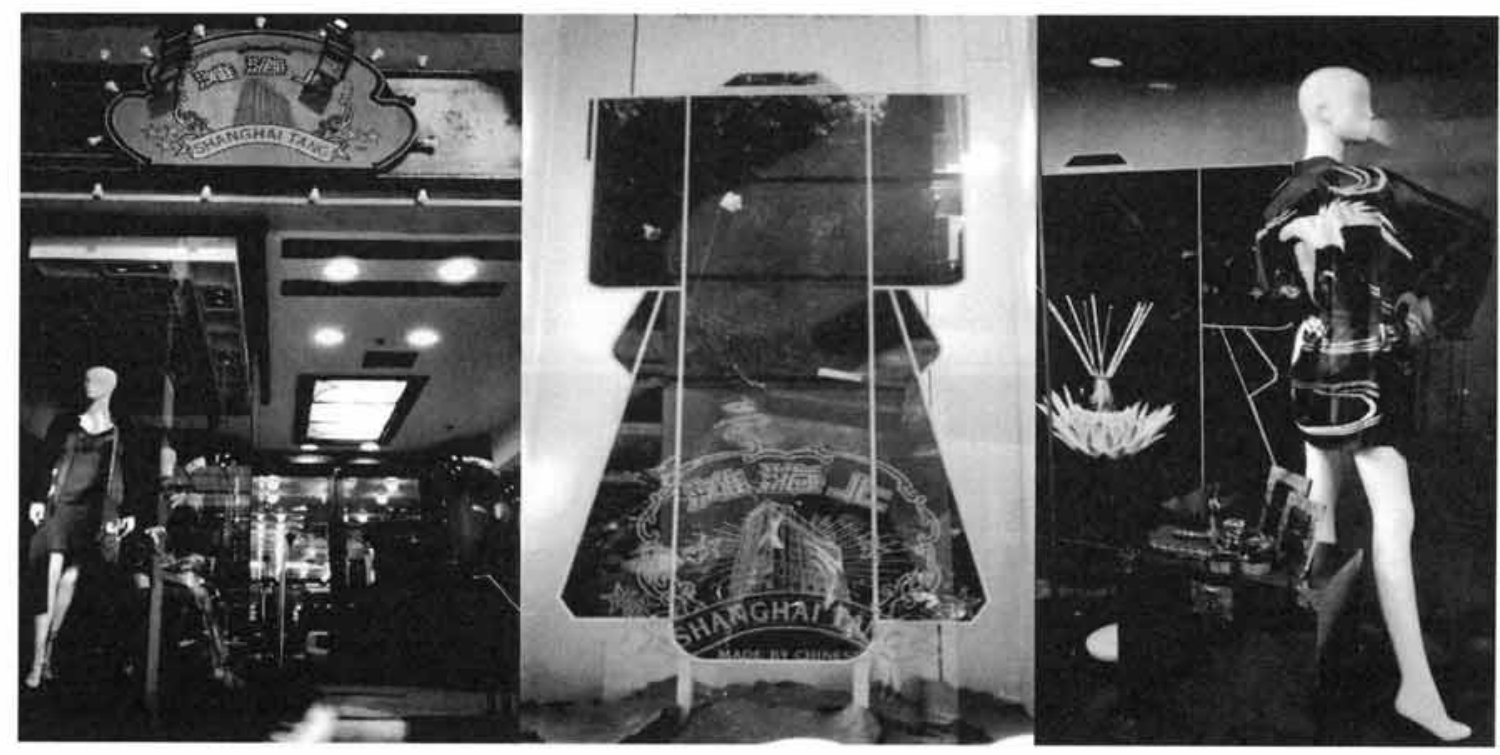

Source: authors' own pictures

does not just follow the beaten luxury track, but who has his own mind and does things differently. Otherwise it is hardly possible for a luxury brand to surprise its customers and to deliver them the expected unexpected.

\subsection{Expansion}

After the opening of his first store on Pedder Street in Hong Kong in 1994, David Tang went on to open his second store, as beautiful as the first one, in New York City three years later. The grand opening in 1997 of the 12,500 square foot store on Madison Avenue prime location was the excitement of the American high society at that time. The duchess of York Sarah Ferguson gave Oprah Winfrey a pair of
Shanghai Tang's signature silk pajamas live on her talk show. The well-known Chinese actress Gong $\mathrm{Li}$ was featured in a print campaign in The New York Times, Vanity Fair, Harper's Bazaar and W (Yim, 2007). However this New York retail operation was a financial disaster. Barely nineteen months after the opening, the store was shut down and quietly relocated to a cheaper location of Madison Avenue (Reena, 2005). The main reasons were: (1) there was an important knowledge gap about American consumers, whose interest for Shanghai Tang's products was largely overestimated. The bright and bold colors matched with 1930's Shanghainese style were overwhelming for American consumers. (2) The style of Shanghai Tang was confusing for customers. There wasn't any consistency in 
the style of the product offerings: they included both pre-revolutionary and Cultural Revolution styles and the post-modern representation of China's heritage. (3) It was difficult to justify the high price of those Chinese products when much cheaper alternatives were readily available in the local Chinatown. (4) The choice of retail space on Madison Avenue prime location was too expensive, US $\$ 2.7 \mathrm{mil}$ lion annually, for the sale volume (Yim, 2007). Besides its failure on the US market, Shanghai Tang products found numerous followers especially among Western tourists and became "souvenir-like" must-haves, However, despite its strong brand DNA, Shanghai Tang business model was neither expandable nor exportable. Consumers who bought a Shanghai Tang "cheongsam" (a traditional Chinese woman's dress) wear it occasionally and hardly need to buy more than two in their lifetime. The brand did not generate enough repeated sales and over the years the company cumulated heavy debts and became unprofitable.

\subsection{Revitalizing: Turning a niche brand into a profitable company}

After purchase by Richemont, Le Masne de Chermont repositioned the brand and undertook some major strategic changes:

1. Making the brand more relevant and wearable: He created an artistic director position and hired Joanne Ooi for this role. Joanne worked closely with Raphael to renew the design of Shanghai Tang products. The brand should not be exotic or ethnic Chinese. They chose to move away from the very traditional $1930^{\circ} \mathrm{s}$ Chinese style to a more contemporary modern Chinese design while still keeping the bright and bold colors that made the brand unique. They also launched two ready-to-wear collections per year. Le Masne de Chermont comments: "our challenge has been to make our collections relevant, wearable and modern" (Jones and Conti, 2006). The new design would allow consumers to wear Shanghai Tang clothing with a pair of jeans on daily basis without losing their elegance.

2. More freedom and responsibilities for designers: Each product category was assigned to a designer who works closely with Le Masne de Chermont and Ooi. The team of designers was in charge of expanding and improving the product offerings in terms of quality and margins.

3. Increasing brand awareness and desire with new advertising print and social media campaigns.

4. Strengthening the presence in travel retail: Shanghai Tang opened stores around the world and in particular in major Asian airports such as Hong Kong, Beijing, Shanghai and Singapore in order to capitalize on the regional tourist market. All 
Shanghai Tang stores are directly operated by the company.

5. Improving customer service: To be consistent with its Asian roots, Shanghai Tang also considers customer service as a main pillar of their business model and put a lot of effort in selecting and training its boutique sales teams. Sales staff is selected on their personality and attitude (kind, pleasant, altruistic, genuine willingness to help others, hard-working, and love what they do). Some of them were recruited from the hospitality sector because of their former training and good sense of service. They are purposely forbidden to make any personal judgment about potential customers in the stores based on their looks. Potential customers of Shanghai Tang can be anybody and sales staff can- not be snobbish towards them. They are also told to behave like the ambassadors of the brand but not the brand. Their main role was to serve the customers, and not tell them what to buy or not buy. Members of a highly prestige-oriented and face-consciousness culture such as China know pretty well how to make people feel valued: Chinese businessmen could exploit their country's expertise in this field in order to compete with Western brands. Le Masne de Chermont strongly believes that selling luxury is selling emotions and, he and his team are working very hard on building a memorable shopping experience in their stores using the five senses: smell (with their home fragrance ginger flower), touch (with leather, silk or cashmere products), music (with Shanghai Tang CDs),

〈Figure 7〉 Raphael Le Masne de Chermont and Flagship Shanghai Tang Mansion in Hong Kong
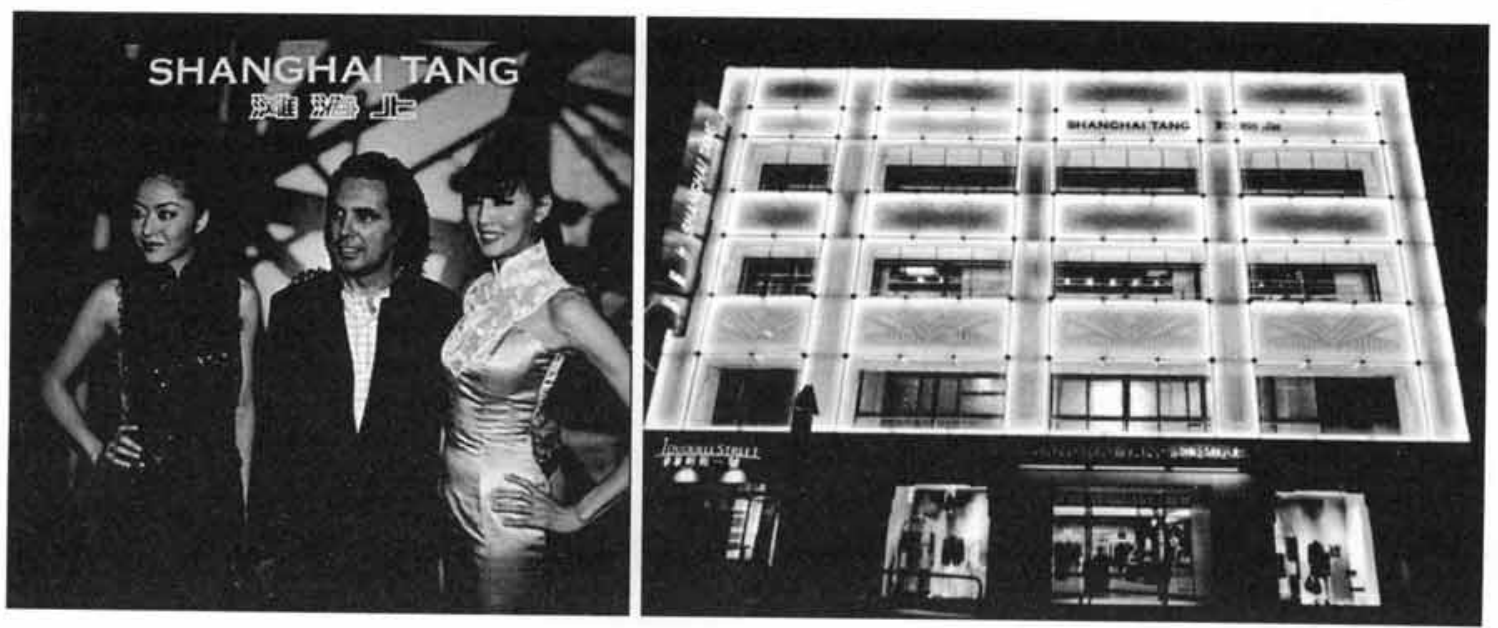

Source: images,businessweek.com/.../source/7.htm 
sight (with colorful store fittings) and taste (with Shanghai Tang café).

\subsection{Deepening \& Expansion: From a niche souvenir brand to a luxury lifestyle brand}

After fifteen months under Raphael's leadership, Shanghai Tang returned to profitability, despite the 2003 SARS (Severe Acute Respiratory Syndrome) crisis affecting severely the travel industry. This achievement was a very significant stage in the life of the company as it reestablished the shareholders confidence in its business model. Raphael then decided to strengthen its giftware line and introduce the accessories line. The product line expansion included homeware, tableware, fragrances, music $C D$ of Shanghai divas, stationary, game sets (such as the well-known Chinese mahjong game), and even a café in their flagship store in Shanghai. With the expansion of its product portfolio (see Figure 8). Shanghai Tang evolved from a souvenir to a luxury lifestyle brand and became accessible to many more consumers and encouraged repeated sales (Bogert and Elliot, 1997). With healthy cash flows, Shanghai Tang could finance new store openings in Americas, Europe and Middle East such as Miami, Honolulu. Madrid, and Kuwait City. At the same time, the company still fully controls its distribution via its stores (no wholesaling). The accessories

〈Figure 8〉 Shanghai Tang's Product Portfolio
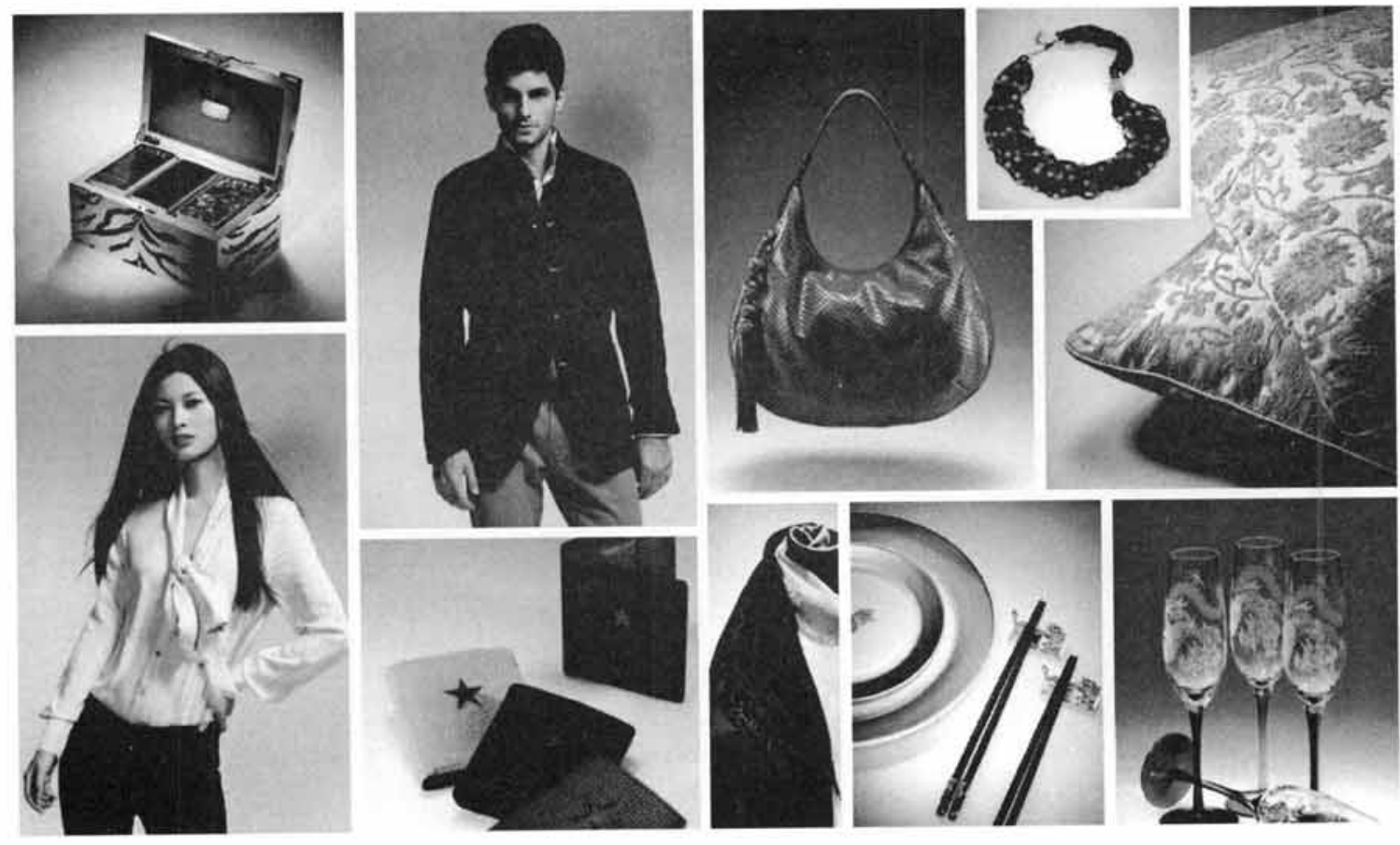
line grew from $5 \%$ to $35 \%$ of the total sales turnover over five years from 2005 to 2010. The growth relies also in a shift of its customer base away from Western tourists towards international and also Chinese customers (Movius, 2009). Today $65 \%$ of the Beijing clientele and $50 \%$ of Shanghai are Chinese and their average spent is $45 \%$ higher than any other nationality. They buy mostly expensive products such as cashmere and leather items. The company also improved its production process while increasing its production capacity and quality to meet the market demand. However, looking mainly at short-term financial results in luxury almost certainly leads to failure. Building a successful luxury brand requires a long-term vision and strategy, time, and heavy resources (Armoudom, 2012).

\subsection{Further Expansion through Viral and Social Media Marketing:}

Instead of focusing on traditional advertising media, Shanghai Tang is building on the brand awareness and authenticity through a sponsorship program of polo tournaments in Mongolia which originated in the $13^{\text {th }}$ century. Shanghai Tang also sponsors elephant polo competitions in Sri Lanka and Thailand, which is a relatively small investment and triggers viral marketing (Montimer 2007). Shanghai Tang has invested in e-commerce (accessible from the main website) and social media such as Facebook, Twitter and iPhone/smartphone applications (see Figure 9). The latter is called "Shanghai Tang City Chic" and includes a city guide of interesting places to see in Beijing and Shanghai. The

〈Figure 9〉 Shanghai Tang on Social Media

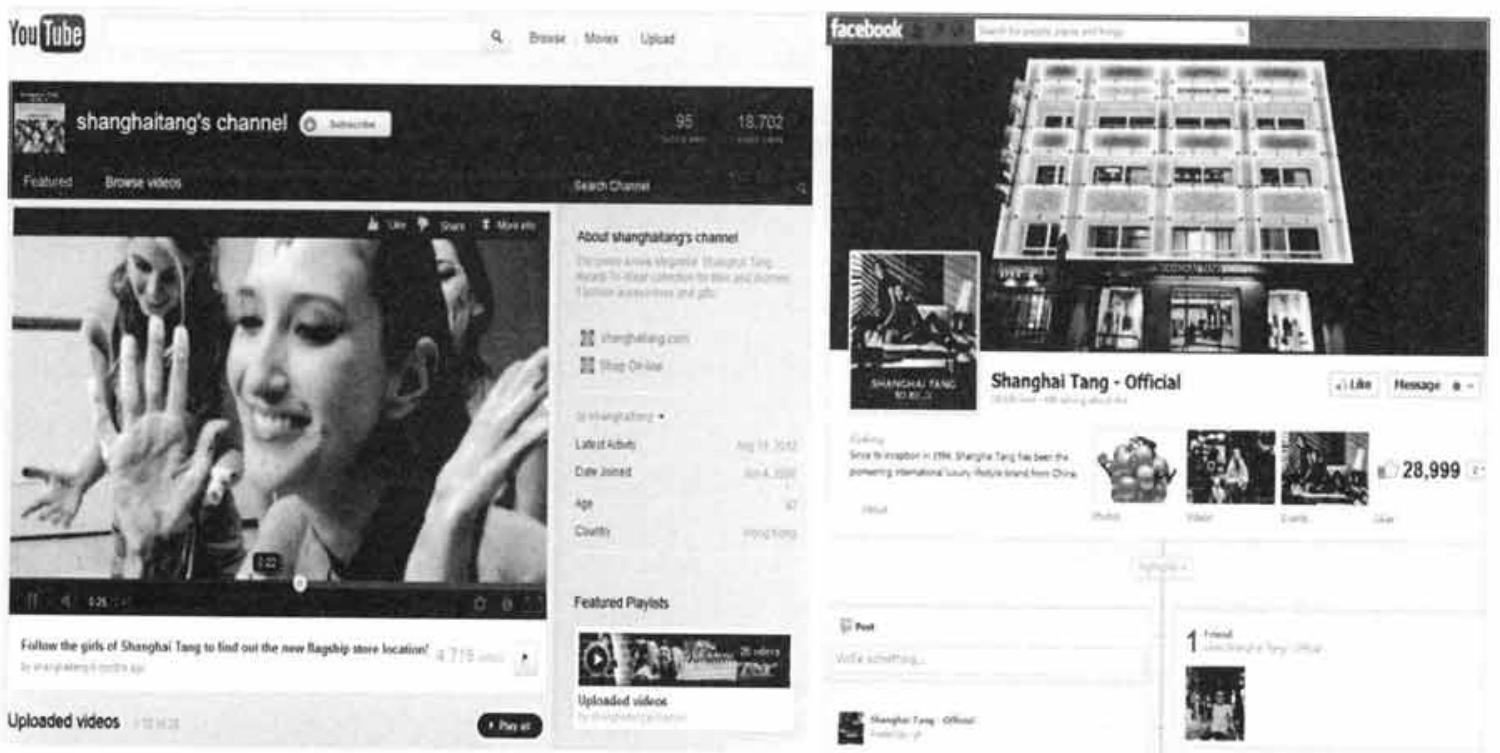


company also has a web blog on modern Chinese chic that talks about anything that relates to modern Chinese chic around the world. However. a short comparison with Gucci or Prada demonstrates that their social media efforts have some scope for further improvements: Gucci has over 10 million while Prada 2.2 million followers on Facebook compared to only 30,500 followers for Shanghai Tang (as of 8 February 2013).

\section{Summary and Conclusions}

Sitting by the windows of the bar at the Fullerton Bay Hotel in Singapore, Raphael Le Masne de Chermont is reflecting upon his years at the helm of Shanghai Tang, the first truly Chinese luxury brand. He believes he has achieved a tremendous contribution to the success of Shanghai Tang. In fact there is very little doubt about it and he can be very proud of it. Since his appointment as Executive Chairman of Shanghai Tang in 2002, Raphael Le Masne de Chermont has successfully turned around a nearly bankrupted company with a niche market positioning into global Chinese luxury lifestyle brand, which serves as a role model for other Chinese luxury brands. This success was not just luck but a truly well-thought through management strategy he has elaborated over the years. However, the road he has been taking is far from being silky-smooth and many challenges still lay ahead of him and his team: how to continue to grow without diluting the company brand DNA? How to grasp a bigger share of the booming Chinese luxury market without alienating his core consumer segments? How to continue to offer a unique luxury shopping experience to his customers while integrating new technologies and social media?

The future challenges for Shanghai Tang over the next few years will definitely be how to capture a larger share of the fast-growing Chinese luxury market. One way of doing so is to open more stores, especially in the secondtier or third-tier cities in China. Raphael already plans a few new store openings. There will be a new store in Harbin, Shenyang and Dalian (China), and two new additional stores in Singapore (one downtown and one at the airport). Most of the company capital investments for the next three years will be in China. However, an exception has been made for Paris, the capital of luxury, fashion, and international tourism. The former Paris store on the "Rive Gauche" (the left bank of the Seine River) was closed down to allow the opening of a new one on the "Rive Droite" (the right bank). Another challenge for Shanghai Tang is how to increase its brand awareness in China without having to spend on traditional media such as television and print advertising.

〈Received February 8. 2013〉

〈Revised March 26. 2013〉

〈Accepted March 27. 2013〉 


\section{References}

Aaker, David A. (1996), Building Strong Brands. New York: The Free Press.

Aaker, Jennifer L. (1997), “Dimensions of Brand Personality," Journal of Marketing Research. 34 (3), 347-356.

Armoudom, Pascal (2012), Luxury Goods: Made in China. ATKearny: Shanghai.

Bain \& Company and Altagamma (2011), Luxury Goods Worldwide Market Study. Munich.

BernsteinResearch (2010), Japan - Lessons from the World's Most Mature Luxury Market. New York.

Bogert, Carroll and Elliot, Dorinda (1997), "David Tang's China Chic," Newsweek 9/22/1997. 130 (12), 48.

Catry, Bernard (2003), "The Great Pretenders: The Magic of Luxury Goods," Business Strategy Review, 14(3), 10 - 17.

Degen, Ronald (2009), “Opportunity for luxury brands in China," working paper no. 31/ 2009, International School of Management, Paris,

Deloitte (2011). The Next Decade in Global Wealth among Millionaire Households, New York.

Eng, Teck-Yong and Bogaert, Julie (2010), “ Psychological and Cultural Insights into Consumption of Luxury Western Brands in India," Journal of Customer Behaviour, 9(1), 55-75.

Esch, Franz-Rudolf (2010). Strategie und Technik der Markenführung, 6th edition, Vahlen, Munich.

Esteve, Gilles and Hieu-Dess, Jasmine (2005), Etude d'une stratégie du luxe - stratégie de Dior. Dissertation, Université Paris-Est., Marne-la-Vallée.

Hedrick-Wong, Yuwa (2007), Succeeding Like Success: The Affluent Consumer of Asia, John Wiley \& Sons (Asia), Singapore.

Heine, Klaus and Trommsdorff, Volker (2008), "Das Marketing von Luxusprodukten," WISU - Das Wirtschaftsstudium, 37(12), 16691674.

Heine, Klaus (2012), The Identity of Luxury Brands, Doctoral dissertation. TU Berlin.

Heine, Klaus (2011), The World Luxury Brand Directory, ISSN: 2193-5440, [www.worldluxurybranddirectory.com]

Heine, Klaus and Phan, Michel (2011), "Tradingup Mass-market Goods to Luxury Products," Australasian Marketing Journal, 19(2), 108114.

John, Doris R. (2008), “Shanghai Tang: Taking Chinese Fashion to the World," ICFAI Journal of International Business, 3 (3). 29-44.

Jones, Nina and Conti, Samantha (2006), "Shanghai Tang Sets New Store Concept," WWD 4/26/2006, 191 (88), 8.

Kapferer, Jean-Noel (2008), The New Strategic Brand Management, 4th edition, Kogan Page, London.

Kapferer, Jean-Noel and Bastien, Vincent (2009a), 
The Luxury Strategy: Break the Rules of Marketing to Build Luxury Brands, Kogan Page, London.

Kapferer, Jean-Noel and Bastien, Vincent (2009b). "The Specificity of Luxury Management: Turning Marketing Upside Down," Journal of Brand Management, 16 (5/6), 311-322.

Kotler, Philip, Keller, Kevin L., Brady, Mairead, Goodman, Malcolm and Hansen, Torben (2009), Marketing Management, Pearson Education, Harlow.

Lu, Pierre Xiao (2008), Elite China: Luxury Consumer Behaviour in China, John Wiley and Sons, Singapore.

McKinsey (2011), Understanding China's Growing Love for Luxury, Shanghai.

Meffert, Heribert and Lasslop, Ingo (2003), Luxusmarkenstrategie. Working paper no. 164. Wissenschaftliche Gesellschaft fur Marketing und Unternehmensfuhrung e.V.. Leipzig.

Montimer, Ruth (2007), "Shanghai Tang Brings Chichi Shops from China," Brand Strategy, 213 (6), 48-49.

Movius, Lisa (2009), "Shanghai Tang Ready to Make Move in China," WWD 9/2/2009, 198 (47), 8.
Nueno, Jose Luis and Quelch, John A. (1998), "The Mass Marketing of Luxury," Business Horizons, 41 (6), 61 - 68.

Prasso, Sheridan (2007), "China's new cultural revolution," CNN Money, 17 May, http:// money.cnn.com/magazines/fortune/fortune _archive/2007/05/28/100034253/index2.htm.

PricewaterhouseCoopers (PwC: 2011). The World in 2050: The Accelerating Shift of Global Economic Power: Challenges and Opportunities, London.

Reena, Jana (2005), "China goes Luxury," BusinessWeek Online 12/1/2005.

Sanderson, Rachel: Hille, Kathrin and Friedman, Vanessa (2012), "Luxury goods: Style Rises in the East," Financial Times online April 8, 2012.

Vernier, Eric and Ghewy, Pierre (2006), La Banalisation Du Luxe. Working paper No. 121, Université du Littoral Côte d'Opale.

Vigneron, Franck and Johnson, Lester W. (2004), "Measuring perceptions of brand luxury," Journal of Brand Management, 11 (6). 484-506.

Yim, Chi Kin and Park, Monica (2007), Shanghai Tang: The First Global Chinese Luxury Brand? Asia Case Research Centre, The University of Hong Kong, 2007. 